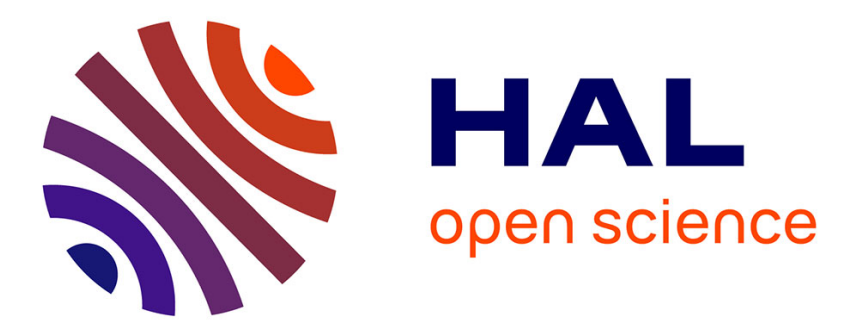

\title{
Population genetics of Chrysomela tremulae: a first step towards management of transgenic Bacillus thuringiensis poplars Populus tremula $\times$ P. tremuloides
}

Anne Genissel, Frédérique Viard, Denis D. Bourguet

\section{- To cite this version:}

Anne Genissel, Frédérique Viard, Denis D. Bourguet. Population genetics of Chrysomela tremulae: a first step towards management of transgenic Bacillus thuringiensis poplars Populus tremula $\mathrm{x}$ P. tremuloides. Hereditas, 2000, 133, pp.85-93. 10.1111/j.1601-5223.2000.00085.x . hal-02699100

\section{HAL Id: hal-02699100 \\ https: / hal.inrae.fr/hal-02699100}

Submitted on 1 Jun 2020

HAL is a multi-disciplinary open access archive for the deposit and dissemination of scientific research documents, whether they are published or not. The documents may come from teaching and research institutions in France or abroad, or from public or private research centers.
L'archive ouverte pluridisciplinaire HAL, est destinée au dépôt et à la diffusion de documents scientifiques de niveau recherche, publiés ou non, émanant des établissements d'enseignement et de recherche français ou étrangers, des laboratoires publics ou privés.

\section{(c)(1)}

Distributed under a Creative Commons Attribution| 4.0 International License 


\title{
Population genetics of Chrysomela tremulae: a first step towards management of transgenic Bacillus thuringiensis poplars Populus tremula $\times P$. tremuloides
}

\author{
ANNE GÉNISSEL ${ }^{1,2}$, FRÉDÉRIQUE VIARD ${ }^{3}$ and DENIS BOURGUET ${ }^{1}$ \\ ${ }^{1}$ Unité de Recherches de Lutte Biologique, INRA La Minière, Guyancourt, France \\ ${ }^{2}$ Station de Zoologie forestière, INRA Centre de Recherches d'Orléans, Ardon, France \\ ${ }^{3}$ Laboratoire de Génétique et d'Evolution des populations végétales (UPRESA CNRS 8016, FR CNRS 1818), \\ Université Lille I, Villeneuve d'Ascq, France
}

\begin{abstract}
Génissel, A., Viard, F. and Bourguet, D. 2000. Population genetics of Chrysomela tremulae: a first step towards management of transgenic Bacillus thuringiensis poplars Populus tremula $\times$ P. tremuloides. - Hereditas 133: 85-93. Lund, Sweden. ISSN 0018-0661. Received July 31, 2000. Accepted October 23, 2000

Many strategies have been proposed for delaying the development of insect resistance to Bacillus thuringiensis (Bt). The current paradigm for $B t$ resistance management is the high dose-refuge strategy. For this strategy to be successful: (i) heterozygotes must be killed in treated areas, (ii) resistant alleles must be rare (frequency $<10-3$ ), and (iii) there must be a high level of gene flow between populations to ensure random mating. We studied gene flow within and between populations with a view to managing the resistance of Chrysomela tremulae (Coleoptera: Chrysomelidae) to new transgenic, highly toxic poplars expressing a synthetic $B t$ gene. In this study, we assessed the extent of gene flow in $C$. tremulae within and between 16 sites in France and Belgium, using allozyme markers. We found a high level of genetic variability in $C$. tremulae, with a mean of $0.206 \pm 0.16$. There were no obvious limitations to gene flow between populations of $C$. tremulae over large geographical distances (several hundreds of kilometres). Nevertheless, a very low level of genetic differentiation was observed between a site located in the south of France and the sampled sites from the Centre region.
\end{abstract}

Denis Bourguet, Unité de Lutte Biologique, INRA La Minière, 78285 Guyancourt, France. E-mail: bourguet@jouy.inra.fr

Plant resistance due to Bacillus thuringiensis $(B t)$ toxin production is, like that due to chemical insecticides, under threat from evolution in the pests (Bishop and Grafius 1996; DeMAagd et al. 1999). This is the conclusion drawn from the rapid genetic adaptation of many target insects to $B t$ toxins in the laboratory. Indeed, since MCGaughey (1985) first reported resistance to a $B t$ toxin in the Indian mealmoth, Plodia interpunctella (Hübner), resistance has been successfully selected in several insect pest species (see Frutos et al. 1999; SANCHIS 2000 for recent reviews).

Various management strategies for reducing selection for $B t$ resistance alleles have been proposed (FRUTOS et al. 1999; Gould 1998; Roush 1998) but the high dose-refuge strategy is generally accepted to be the most effective (ALSTAD and ANDOW 1995; ANDOw et al. 1998; MALleT and PORTER 1992). This strategy is considered to be the best approach for managing transgenic crops and is currently recommended for $B t$ cotton and $B t$ maize in North America (OstLIE et al. 1997). The underlying theory is that random gene exchange between selected (in transgenic areas) and unselected (in non- $B t$ areas, referred to as refuges) insect populations can delay the evolution of resistance.
As pointed out by ANDOw et al. (1998), the high dose-refuge strategy may not be effective if three conditions are not satisfied. First, the dose of toxin produced by $B t$ plants must be sufficiently high to kill heretozygous individuals, thus making the fitness conferred by the resistance allele recessive (Bourguet et al. 2000a). Second, the frequency of alleles decreasing $B t$ toxin susceptibility must be low $\left(<10^{-3}\right)$ so that only a few resistant homozygotes are likely to survive on $B t$ crops. Third, random mating must occur between resistant and susceptible homozygotes.

Most of the insecticidal cultivars are arable crops into which $B t$ genes have been inserted. However, trees with $B t$ genes have also been engineered, for resistance against phytophagous species (ELLIS and RAFFA 1997). The sustainability of the resistance in these transgenic trees depends on the rate of selection of $B t$ resistance alleles in target populations. Taking this environmental risk into account is of particular importance due to the longevity of trees (STRAUSS et al. 1991).

Most of the transgenic trees produced are hybrid poplars (ELLIS and RAFFA 1997; LEPLÉ et al. 1999) expressing $B t$ genes, resulting in very low levels of feeding damage (MEILAN et al. in press). We have 
Table 1. Characteristics of samples of Chrysomela tremulae: location, date of sampling and number $(N)$ of sample sites analysed

\begin{tabular}{|c|c|c|c|c|c|c|c|}
\hline Country - Region & Department & Location & Population & Latitude & Longitude & Date & $\mathrm{N}$ \\
\hline \multirow[t]{10}{*}{ France - Centre } & \multirow[t]{5}{*}{ Loiret } & Ardon & Ard & $47^{\circ} 49 \mathrm{~N}$ & $1^{\circ} 55 \mathrm{E}$ & $14-05-99$ & 36 \\
\hline & & Marcilly en Villette & Vil & $47^{\circ} 46 \mathrm{~N}$ & $1^{\circ} 58 \mathrm{E}$ & 14-05-99 & 40 \\
\hline & & $\begin{array}{l}\text { Nogent sur } \\
\text { Vernisson }\end{array}$ & Nog & $47^{\circ} 50 \mathrm{~N}$ & $2^{\circ} 47 \mathrm{E}$ & $13-05-99$ & 42 \\
\hline & & Ligny le Ribeault & Lig & $47^{\circ} 39 \mathrm{~N}$ & $1^{\circ} 47 \mathrm{E}$ & $14-05-99$ & 21 \\
\hline & & Fay aux Loges & For & $47^{\circ} 56 \mathrm{~N}$ & $2^{\circ} 10 \mathrm{E}$ & $16-05-99$ & 41 \\
\hline & \multirow[t]{2}{*}{ Loir et Cher } & Marchenoir & Che & $47^{\circ} 53 \mathrm{~N}$ & $1^{\circ} 16 \mathrm{E}$ & $12-05-99$ & 41 \\
\hline & & $\begin{array}{l}\text { Chaumont sur } \\
\text { Tharonne }\end{array}$ & Cha & $47^{\circ} 36 \mathrm{~N}$ & $1^{\circ} 58 \mathrm{E}$ & $10-05-99$ & 42 \\
\hline & Eure et Loire & Dangeau & Dan & $48^{\circ} 11 N$ & $1^{\circ} 15 \mathrm{E}$ & $12-05-99$ & 41 \\
\hline & \multirow[t]{2}{*}{ Indre } & Vatan & Vat & $47^{\circ} 5 \mathrm{~N}$ & $1^{\circ} 45 \mathrm{E}$ & $27-05-99$ & 40 \\
\hline & & Vatan & Vaa & $47^{\circ} 4 \mathrm{~N}$ & $1^{\circ} 45 \mathrm{E}$ & $27-05-99$ & 28 \\
\hline \multirow[t]{2}{*}{ France - Lorraine } & \multirow[t]{2}{*}{ Vosges } & Contrexéville & Coo & $48^{\circ} 12 \mathrm{~N}$ & $5^{\circ} 52 \mathrm{E}$ & $19-05-99$ & 21 \\
\hline & & Contrexéville & Con & $48^{\circ} 12 \mathrm{~N}$ & $5^{\circ} 52 \mathrm{E}$ & 19-05-99 & 24 \\
\hline France - Picardie & Oise & Berneuil sur Aisne & Ami & $49^{\circ} 25 \mathrm{~N}$ & $3^{\circ} \mathrm{E}$ & $05-06-99$ & 31 \\
\hline $\begin{array}{l}\text { France - Champagne-Ar- } \\
\text { denne }\end{array}$ & Ardennes & Bouconville & Bou & $49^{\circ} 16 \mathrm{~N}$ & $4^{\circ} 47 \mathrm{E}$ & $08-06-99$ & 32 \\
\hline France - Midi-Pyrénées & Ariège & Moulis & Mou & $42^{\circ} 58 \mathrm{~N}$ & $1^{\circ} 5 \mathrm{E}$ & $07-06-99$ & 10 \\
\hline Belgique - Wallonie & Hainault & Oignies & Oig & $50^{\circ} 26 \mathrm{~N}$ & $4^{\circ} 35 \mathrm{E}$ & $30-05-99$ & 36 \\
\hline
\end{tabular}

recently engineered and assessed new transgenic hybrid poplars Populus tremula $\times P$. tremuloides expressing a synthetic $B t$ cry $3 A$ gene (GéNISSEL et al. unpublished data). One target of the Cry $3 \mathrm{~A}$ toxin is the poplar leaf beetle, Chrysomela tremulae F. This species is a polyvoltine and oligophagous beetle responsible for sporadic but highly destructive attacks on native and introduced hybrid poplars (AUGUSTIN and LéviEuX 1993). The predicted benefits for the tree-growing industry (RAFFA 1989), may result in $B t$ poplars in intensive cultivation being rapidly introduced at the field scale in Europe, providing favourable conditions for the selection of Cry3A resistance in the $C$. tremulae population.

Our $B t$ poplar produced very high levels of toxin (GéNISSEL et al. unpublished data), so the high doserefuge strategy may be considered for managing resistance. The first requirement of this strategy (the resistance must be recessive) cannot be evaluated until the selection of $C$. tremulae strains resistant to the Cry3 A toxin are selected. The second requirement (resistance alleles must be rare) is currently under investigation and will be reported elsewhere. The aim of this study was to provide insight into the third requirement of the high dose-refuge strategy, that there must be extensive gene flow within and between $C$. tremulae populations. We therefore assessed the extent of gene flow in C. tremulae within and between 16 sites in France and Belgium.

\section{MATERIALS AND METHODS}

\section{Sampling sites}

Samples were taken from 16 sites in France and Belgium (Table 1, Fig. 1). We collected first-generation adults. Adults were removed from poplar leaves at each site sampled and frozen at $-80^{\circ} \mathrm{C}$.

This is the first study to evaluate the genetic diversity and structure of natural populations of Chrysomela tremulae. As the geographic level at which genetic differentiation could occur was unknown, we carried out a hierarchical sampling of 16 natural populations covering a large geographical 
area in France and Belgium. Eight of the 16 sites were in the centre of France (populations Cha, Dan, Che, Nog, Ard, Vil, Lig, For) and for two locations, 2 populations (Vat and Vaa; Con and Coo), separated by 200 and 50 metres, respectively, from each other, were sampled.

\section{Electrophoresis}

Each individual was homogenised in $250 \mu \mathrm{l}$ of $0.4 \%$ NADP Tris-EDTA buffer ( $\mathrm{pH}$ 6.8), after discarding the head, thorax and wings. The homogenates were subjected to horizontal starch gel electrophoresis using Tris-borate-EDTA ( $\mathrm{pH} \mathrm{8.6)} \mathrm{and} \mathrm{Tris-citrate}(\mathrm{pH}$ 6.8) buffer systems (PASTEUR et al. 1987). Enzymes were detected using staining techniques adapted from those described by PASTEUR et al. (1987) and the TPI protocol, adapted from that described by BOURGUET et al. (2000b). Twenty-two enzyme systems were studied, but only seven were retained, on the basis of their unequivocal genetic interpretation and polymorphisms. These enzyme systems were phosphoglucomutase (PGM, EC 5.4.2.2), mannose-6-phosphate isomerase (MPI, EC 5.3.1.8), hydroxybutyrate dehydrogenase (HBDH, EC 1.1.1.30), glucose-phosphate isomerase (GPI, EC 5.3.1.9), creatine kinase (CK, EC 2.7.3.2), triose phosphate isomerase (TPI, EC 5.3.1.1), and one dipeptidase, using L-leucyl-DL-alanine as substrate (PEP-LA, EC 3.4.13.11).

\section{Data analysis}

For each sampled site, allelic frequencies (see appendix 1 for details), the mean number of alleles $\left(N_{a l l}\right)$, the observed heterozygosity $\left(H_{o}\right)$, the unbiased

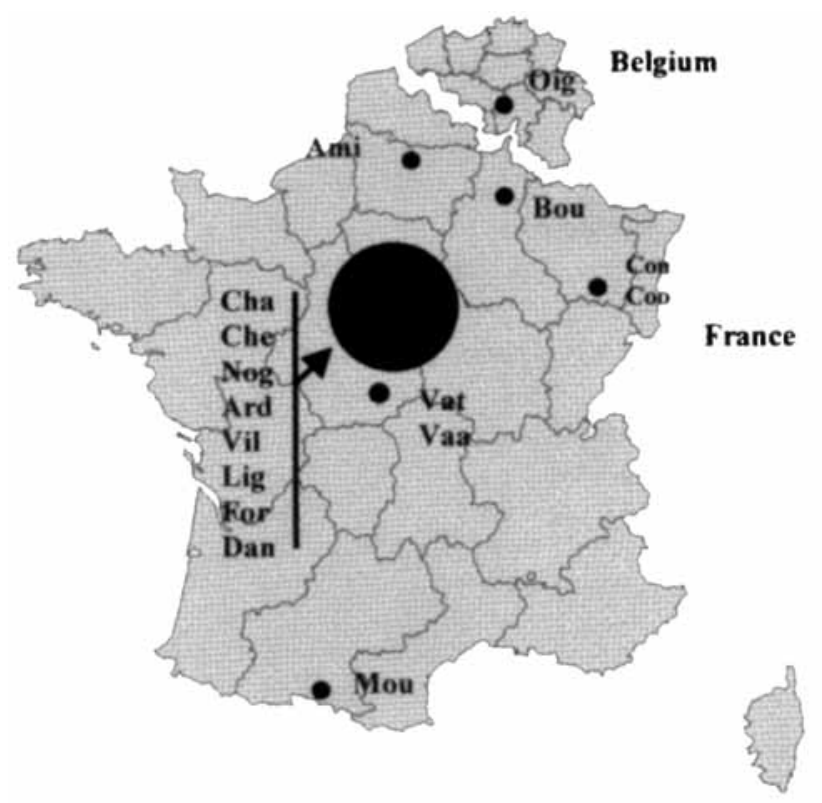

Fig. 1. Geographical location of the 16 sites sampled. expected heterozygosity, as described by NEI et al. (1978) $\left(H_{e}\right), \hat{f}$-values (i.e. $F_{i s}$ estimates as described by WEIR and COCKERHAM 1984) and polymorphism at $95 \%$ and $99 \%$ thresholds were estimated using GENETIX 4.0 software (BELKIR 2000). $N_{\text {all }}, H_{o}, H_{c}$ and $\hat{f}$ were calculated for all individuals and loci. Tests for deviations from Hardy-Weinberg equilibrium at each locus and for genotypic linkage disequilibrium between loci were performed for each sampled site with GENEPOP 3.2 (RAYMOND and ROUSSET 1995).

The genetic structure at sites over the whole study area, or at sites from a restricted area (to test for regional effects), for each of the 7 polymorphic loci and for all of the loci, was analysed by testing for allelic differentiation using exact tests and by calculating the estimator $\hat{\theta}$ of $F_{s t}$ as described by WEIR and Cockerham (1984), using GENEPOP 3.2 (RAYMOND and RousSET 1995). The significance of $\hat{\theta}$-values was determined by resampling methods (bootstrapping over loci) to determine $95 \%$ confidence intervals, using FSTAT 2.8 (GOUDET 1995). A hierarchical analysis was also conducted by clustering populations belonging to restricted geographic areas. Three groups were defined: the populations sampled in the centre of France (Cha, Dan, Che, Nog, Ard, Vil, Lig, For) plus Vat-Vaa, the populations sampled in the east of France and Belgium (Con-Coo, Bou, Oig and Ami) and a population from the south of France (Mou). Hierarchical analyses of population structure were performed by partitioning $\hat{\theta}$ into $\hat{\theta}_{s}$ and $\hat{\theta}_{p}$, indicating differentiation within and between groups, respectively. Those calculations were done with TFPGA 1.3 (MILLER 1997). Isolation by distance patterns (SLATKIN 1993) were also investigated by analysing the independence of geographic and genetic distances. The null hypothesis of independence of geographic from genetic distances was tested against a hypothesis of positive correlation expected under isolation by distance, estimated as Spearman's rank correlation coefficient. The observed correlation coefficient was compared to the distribution of correlation coefficients obtained from Mantel-like permutations of the genetic $(\hat{\theta} /(1-\hat{\theta}))$ and geographic $(\mathrm{ln}$ (geographic distance)) matrices, using GENEPOP 3.2 .

\section{RESULTS}

Of the 16 samples analysed, eight, six, four, eight, seven, seven and four alleles were observed for the loci Tpi, Gpi, Hbdh, Ck, Mpi, Pgm and Pep respectively (Table 2). Exact tests for genotypic linkage disequilibrium gave non-significant values in $21 \mathrm{com}$ bined tests for each locus pair across all sampled 
Table 2. Within-site genetic parameters. Each site is named. The mean number of alleles $\left(N_{\text {anl }}\right)$, observed heterozygosity $\left(H_{o}\right)$ and gene diversity $\left(H_{e}\right)$ are given, as well as estimates of the $\hat{f}$-values and $P$-values of the test for deviation from Hardy-Weinberg equilibrium per population, for seven loci (Tpi, Gpi, Hbdh, Ck, Mpi, Pgm and Pep, see text for details)

\begin{tabular}{|c|c|c|c|c|c|c|c|c|}
\hline & \multicolumn{2}{|l|}{$N_{\text {all }}$} & \multicolumn{2}{|l|}{$H_{o}$} & \multicolumn{2}{|l|}{$H_{e}$} & \multirow[t]{2}{*}{$\hat{f}$} & \multirow[t]{2}{*}{$P$} \\
\hline & Mean & S.E. & Mean & S.E. & Mean & S.E. & & \\
\hline Cha & 3.57 & 0,79 & 0.21 & 0.11 & 0.27 & 0.14 & 0.219 & 0.002 \\
\hline Dan & 3.29 & 1,11 & 0.24 & 0.14 & 0.25 & 0.15 & 0.067 & 0.54 \\
\hline Che & 2.71 & 0,49 & 0.21 & 0.12 & 0.25 & 0.15 & 0.098 & 0.58 \\
\hline Nog & 3.57 & 1,51 & 0.25 & 0.18 & 0.26 & 0.19 & 0.049 & 0.49 \\
\hline Ard & 2.86 & 1,07 & 0.21 & 0.17 & 0.24 & 0.15 & 0.128 & 0.01 \\
\hline Vil & 3.29 & 0,76 & 0.25 & 0.15 & 0.27 & 0.16 & 0.062 & 0.78 \\
\hline Lig & 3.29 & 1,11 & 0.28 & 0.17 & 0.28 & 0.15 & -0.007 & 0.71 \\
\hline For & 3.29 & 0,76 & 0.22 & 0.15 & 0.25 & 0.18 & 0.120 & 0.14 \\
\hline $\mathrm{CoO}$ & 3.29 & 1,50 & 0.30 & 0.20 & 0.26 & 0.17 & -0.137 & 0.99 \\
\hline Con & 2.86 & 0,38 & 0.25 & 0.17 & 0.27 & 0.16 & 0.094 & 0.33 \\
\hline Vat & 3.57 & 1,40 & 0.28 & 0.18 & 0.27 & 0.13 & -0.004 & 0.12 \\
\hline Vaa & 3.71 & 1,50 & 0.26 & 0.16 & 0.24 & 0.15 & -0.042 & 0.85 \\
\hline Mou & 3.29 & 0,95 & 0.40 & 0.24 & 0.37 & 0.16 & -0.084 & 0.88 \\
\hline Ami & 3.71 & 1,25 & 0.27 & 0.12 & 0.28 & 0.13 & 0.070 & 0.83 \\
\hline Bou & 3.29 & 1,11 & 0.27 & 0.20 & 0.26 & 0.17 & -0.059 & 0.62 \\
\hline Oig & 3.00 & 0,82 & 0.26 & 0.14 & 0.27 & 0.15 & 0.053 & 0.66 \\
\hline
\end{tabular}

sites. The proportion of polymorphic loci for the $95 \%$ criterion was $71 \%$ to $100 \%$ depending on the population and was $100 \%$ in all populations for the $99 \%$ criterion. Within samples (Table 2), the mean number of alleles was from 2.71 to 3.71 for the 7 loci used. The observed and expected heterozygosities were almost identical and were from 0.21 to 0.40 and 0.23 to 0.35 , respectively (Table 3 ). The estimates of $\hat{f}$-values showed no large excess or deficit of heterozygotes, and deviations from Hardy-Weinberg equilibrium for the seven loci were significant at only two of the 16 sites sampled (Cha $(P=0.002)$ and Ard $(P=0.01))$. Heterozygote deficiencies at these two sites were attributed mainly to high $\hat{f}$ values for the Pgm locus, 0.497 and 1 respectively. Deviations from Hardy-Weinberg equilibrium were observed in four populations for this locus (Cha $(P=0.005)$, Ard $(P=0.0001)$, Con $(P=0.007)$, and Vat $(P=0.04))$.

At the smallest geographical scale studied (i.e. between Vat and Vaa, and between Con and Coo), no allelic differentiation was observed. The probability value (Fisher's method) for the Vat/Vaa and Con/ Coo population pairs for all loci was 0.40 and 0.72 , respectively. Moreover, pooled data sets (Vat pooled with Vaa and Con pooled with Coo) showed no deviation from Hardy-Weinberg equilibrium. To avoid mean distance biases between pairs of samples when analysing the whole data set (see below), we pooled these data and analysed thereafter 14 samples.

Similar results were obtained on a regional scale. The eight samples from the centre of France (Chan, Dan, Che, Nog, Ard, Vil, Lig, For), showed no allelic differentiation $(P=0.11)$ and null $\hat{\theta}$ values were obtained. No isolation by distance was observed (Mantel test: $P=0.63$ ). This was also true for analysis both in the same data set of the Vat and Vaa samples ( $P=0.16, \hat{\theta}=0.000$, Mantel test: $P=0.74)$. Thus, on a small geographical scale (a few hundred meters) and on regional scale, populations did not appear to be genetically structured.

On a larger scale (the whole study), overall allelic differentiation between the 14 samples (Vat and Vaa, and Con and Coo were pooled), was highly significant $(\mathrm{P}=0.013)$. This was due to two (Tpi and Gpi) of the seven loci. It was associated with a low mean $\hat{\theta}$-value $(\hat{\theta}=0.002)$, not significant if the bootstrapping method was used over loci $(95 \%$ confidence interval $\hat{\theta}=[-0.004 ; 0.005])$. Finally, the hierarchical analyses yielded similar results, with low and non-significant $\hat{\theta}_{s}$ and $\hat{\theta}_{p}$ values obtained when taking

Table 3. Overall genetic differentiation ( $\hat{\theta}$-values estimated as described by WEIR \& COCKERHAM (1984)) for the 7 loci, for 14 sample sites

\begin{tabular}{lrll}
\hline & \multicolumn{1}{l}{} & $P$ & S.E. \\
\hline Tpi & 0.010 & 0.003 & 0.001 \\
Gpi & 0.009 & 0.002 & 0.001 \\
Hbdh & -0.002 & 0.331 & 0.02 \\
Ck & -0.005 & 0.489 & 0.03 \\
Mpi & -0.003 & 0.105 & 0.01 \\
Pgm & -0.005 & 0.625 & 0.03 \\
Pep & 0.002 & 0.326 & 0.03 \\
All loci & 0.002 & 0.013 & \\
\hline
\end{tabular}




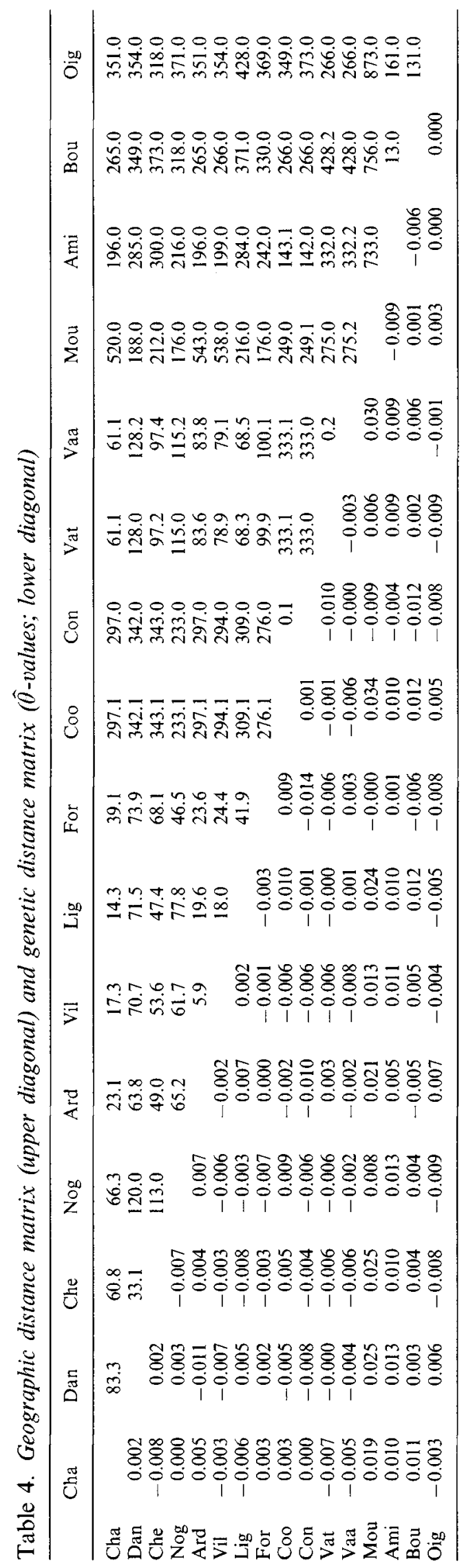

into account that populations belonged to different regions. $\hat{\theta}_{s}$ and $\hat{\theta}_{p}$ were 0.002 and 0.004 respectively and $95 \%$ bootstrap confidence intervals were $[0$; 0.001 ] for both. When calculating the probability values in exact tests for differentiation between groups, a highly significant difference $(\mathrm{P}=0.0003)$ was observed between populations in the center of France plus Vat-Vaa and the Mou population. In pairwise $\hat{\theta}$ calculations (Table 4 ), the highest values were obtained in comparisons between the Mou sample and the others. However, the Mantel-like test for independence between geographic and genetic distances (Table 4 ) was only marginally significant over the whole data set $(P=0.055)$.

\section{DISCUSSION}

This study of the genetic structure of $C$. tremulae populations in France and Belgium, based on allozyme markers, is the first study of the genetic structure of natural populations of this species. It reveals a high degree of gene flow within and between sampled sites on all geographical scales.

At the site level, significant deviation from HardyWeinberg equilibrium was observed for two of the 16 sites sampled. These heterozygote deficiencies were mainly due to one locus, Pgm. Heterozygote deficiencies were observed at this locus in four of the 16 samples. If the low heterozygosity of this locus had arisen from non-random mating, it would have affected all seven neutral loci in the same way. The most likely explanation for the deficiencies in the four samples is technical problems in resolving heterozygotes, although there may be selection acting on this locus. Overall, the lack of deviation from HardyWeinberg equilibrium strongly suggests that the observed genetic structure is highly stable, with panmixia among individuals collected at the sampled sites.

Over the whole study (on the largest spatial scale) a very low level of genetic differentiation was observed, especially between the site in the south of France (Mou) and the sites from the Centre region. The Mou sample was very small (10 individuals) and no other populations from that area were analysed. Further sampling in the south would therefore be necessary before: $(i)$ concluding that there was a genetic differentiation between the southern and northern areas and (ii) analysing the slight (and non-significant for this data set) isolation by distance pattern observed. The major result of this study is the finding that there are no obvious limitations to gene flow between populations of $C$. tremulae over large geographical distances (several hundreds of kilometres). 
Several authors have used allozyme markers to investigated the population genetics of various Chrysomelidae species (JACOBSON and HsIAO 1983; KRAFSUR et al. 1995; MCDONALD et al. 1985; RowELL-RAHIER and PASTEELS 1994). In this order, the genetic structure of populations of Plagiodera versicolora (MCCAULEY et al. 1988), Chrysomela aeneicollis (RANK 1992), Phratora vitellinae (CARSTENS 1994), and Oreina cacaliae (KNOLL et al. 1996) have been studied using hierarchical sampling. In contrast with our results, genetic differentiation was found at the largest (between populations several hundred kilometres apart) and lowest (between groups of closely related individuals) levels. In Phratora, Gonioctena and Oreina, the genetic differentiation between regions was often due to geographical barriers such as mountain ridges (CARSTENS 1994; KNOLL et al. 1996). In these genera, some species also displayed genetic isolation by distance at geographical scales of $20 \mathrm{~km}$ to $200 \mathrm{~km}$. The slight genetic differentiation of the Mou population may be due to the Massif Central, which may restrict the gene flow of $C$. tremulae.

Two main ecological characteristics of $C$. tremulae have a major effect on gene flow. The first is habitat persistence. Transient, patchily distributed habitats increase migration between populations, so gene flow is expected to be greater in species that occupy temporary habitats (GANDON et al. 1998; VIARD et al. 1996). This may be the case for $C$. tremulae, which is known to feed in temporary and pioneer habitats because poplar trees recolonise forest sites after disturbances (STETTLER et al. 1996). Gene flow is also affected by dispersal ability. The transient habitat of C. tremulae has resulted in the selection of adaptive features for the finding of new host-plant patches and resources for future generations.

In Chrysomelidae species, allozyme markers display a high and homogeneous level of heterozygosity. For example, the North American species C. scripta, which is related to $C$. tremulae, has a Nei's mean heterozygosity per locus of $0.201 \pm 0.04$ (KRAFSUR et al. 1995) close to that of $L$. decemlineata $(0.206 \pm$ 0.039) (JACOBSON and HSIAO 1983) and that of French C. tremulae populations $(0.2717 \pm 0.158$, Table 2). This genetic variability has important evolutionary consequences as it directly affects the probability and magnitude of adaptive responses to environmental changes (AMOs and HARWOOD 1998). Pesticide treatment is one of the best known examples of such environmental changes. Population genetics has provided relevant information for tracking and managing the adaptation to this man-made change (LENORMAND et al. 1999). Not surprisingly, gene flow within and between populations is considered to be one of the key components in the sustainability of transgenic insecticidal crops and trees. As stressed by BOURGUET et al. (2000b), high level of gene flow have two effects: (i) the spreading of resistance alleles over a large geographical area and (ii) the reduction in local resistance to $B t$ toxins with the immigration of susceptible individuals from non- $B t$ plants. This second conclusion must be considered with care. Indeed to significantly delay the evolution of resistance the level of migration from populations under $B t$ selection must be far greater than the amount of migration needed to homogenise the genetic diversity of populations which are not under selection (as measured is the present study). Thus, while the results of this paper are encouraging, they can hardly be used to ascertain that the current levels of gene flow are of sufficient magnitudes to strongly delay the selection of $B t$ resistance alleles.

The present results must therefore be strengthened by further studies at small geographical scale. Given the low level of gene diversities for our allozyme markers, one possibility is the development of more polymorphic markers such as microsatellites. The second and complementary approach would be an estimation of the migration level from one poplar area to another using mark release recapture experiments. In this latter case the manipulation of the density level of $C$. tremulae in poplar field (in order to mimic $B t$ selection) could be considered.

Finally, more data on the genetic characteristics of $B t$ resistance alleles (e.g., resistance ratio, dominance levels, initial allele frequencies, fitness costs) are required before deciding on the best management strategy for $B t$ poplars.

\section{ACKNOWLEDGEMENTS}

We thank Marie-Therèse Bethenod for preliminary electrophoresis and Sylvie Augustin, Claudine Courtin, Yannis Theau, Alain Chermette, Pierre Fedou, and François Clauce for helpful sampling, and especially Jacques Pasteels for providing the Belgian population. We also thank an anonymous reviewer for helpful comments. A. G. holds a Région Centre Fellowship ( ${ }^{\circ} \mathrm{BTH}$ 00576). This work was supported by the INRA Action Incitative Programmée "OGM et Environnement" and the MENRT A.O. "Impacts des OGM". 


\section{REFERENCES}

Alstad DN and Andow DA, (1995). Managing the evolution of insect resistance to transgenic plants. Science 268: 1894-1896.

Amos W and Harwood J, (1998). Factors affecting levels of genetic diversity in natural populations. Phil. Trans. R. Soc. Lond. B 353: 177-186.

Andow DA, Alstad DN, Pang Y-H, Bolin PD and Hutchison WD, (1998). Using an F2 screen to search for resistance alleles to Bacillus thuringiensis toxin in European corn borer (Lepidoptera: Crambidae). J. Econ. Entomol. 91: 579-584.

Augustin S and Lévieux J, (1993). Life history of the poplar beetle Chrysomela tremulae in the central region of France. Can. Entomol. 125: 399-401.

Bishop BA and Grafius EJ, (1996). Insecticide resistance in the Colorado potato beetle. In: Chrysomelidae Biology: The Classification, Phylogeny and Genetics (eds PHA Jolivet and ML Cox), SPB Academic Publishing, Amsterdam, p. $355-377$.

Belkir K, (2000). Genetix software for Windows TM for population genetics. Laboratoire Génome et Populations, CNRS UPR 9060, Université de Montpellier II, Montpellier.

Bourguet D, Génissel A and Raymond R, (2000a). Insecticide resistance and dominance levels. J. Econ. Entomol. 93: $1588-1595$.

Bourguet D, Bethenod M-T, Pasteur N and Viard F, (2000b). Gene flow in the European corn borer Ostrinia nubilalis: implications for the sustainability of transgenic insecticidal maize. Proc. R. Soc. Lond. B 267: 117-122.

Carstens H, (1994). A comparison of genetic differentiation in European populations of Phratora vitellinae Linné (Coleoptera: Dystiscidae). Heredity 69: 503-511.

DeMaagd RA, Bakker P, Staykov N, Dukiandjiev S, Stiekeman W and Bosch D, (1999). Identification of Bacillus thuringiensis delta-endotoxin Cry1C domain III amino acid residues involved in insect specificity. Appl. Environ. Microbiol. 65: 4369-4374.

Ellis DD and Raffa KF, (1997). Expression of transgenic Bacillus thuringiensis delta-endotoxin in poplar. In: Micropropagation, Genetic Engineering, and Molecular Biology of Populus (eds NB Klopfenstein, YW Chun, M-S Kim, and MR Ahuja), Rocky Mountain Forest and Range Experiment Station, Fort Collins, p. 178-186.

Frutos R, Rang C and Royer M, (1999). Managing insect resistance to plants producing Bacillus thuringiensis toxins. Crit. Rev. Biotech. 19: 227-276.

Gandon S, Ebert D, Oliveiri I and Michalakis Y, (1998). Differential adaptation in spatially heterogeneous environments and host-parasite coevolution. In: Genetic structure and local adaptation in natural insect populations. Effects of Ecology, Life History, and Behavior. (eds S Mopper and SY Strauss), Chapman \& Hall, New York, p. 325-342.

Goudet J, (1995). Fstat version 1.2. A computer program to calculate F-statistics. J. Hered. 86: 485-486.

Gould F, (1998). Sustainability of transgenic insecticidal cultivars: integrating pest genetics and ecology. Annu. Rev. Entomol. 43: 701-726.

Jacobson JW and Hsiao TH, (1983). Isozyme variation between populations of the Colorado potato beetle, Leptinotarsa decemlineata (Coleoptera: Chrysomelidae). Ann. Entomol. Soc. Am. 76: 162-166.
Knoll S, Rowell-Rahier M, Mardulyn P and Pasteels JM, (1996). Spatial genetic structure of leaf beetle species with special emphasis on alpine populations. In: Chrysomelidae Biology, The Classification, Phylogeny and Genetics (eds PHA Jolivet and ML Cox), SPB Academic Publishing, Amsterdam, p. 379-388.

Krafsur ES, Vos J, Nariboli P, and Marquez G, (1995). Gene diversity at allozyme loci in the cottonwood leaf beetle, Chrysomela scripta. Biochem. Genet. 33: 83-89.

Lenormand T, Bourguet D, Guillemaud T and Raymond M, (1999). Tracking the evolution of insecticide resistance in the mosquito Culex pipiens. Nature 400: $861-$ 864.

Leplé J-C, Pilate G and Jouanin L, (1999). Transgenic poplar trees (Populus species). Biotech. Agr. Forest. 44: $221-244$

Mallet $\mathbf{J}$ and Porter P, (1992). Preventing insect adaptation to insect-resistant crops: are seed mixtures or refugia the best strategy? Proc. R. Soc. Lond. B 250: 165-169.

McCauley DE, Wade MJ, Breden FJ and Wohltman M, (1988). Spatial and temporal variation in group relatedness from the imported willow leaf beetle. Evolution 42: 184-192.

McDonald IC, Krysan JL and Johnson OA, (1985). Genetic variation within and among geographic populations of Diabrotica barberi (Coleoptera: Chrysomelidae). Ann. Entomol. Soc. Am. 78: 271-278.

McGaughey WH, (1985). Insect resistance to the biological insecticide Bacillus thuringiensis. Science 229: 193-195.

Meilan R, Ma C, Cheng S, Eaton JA, Miller LK, Crockett RP, DiFazio SP and Strauss SH. High levels of Roundup and leaf-beetle resistance in genetically engineered hybrid cottonwoods. In: Hybrid poplars in the Pacific Northwest: Culture, Commerce, and Capability (eds KA Blatner, JJ Johnson and DM Baumgartner), Washington State University Cooperative Extension, Pullman, (in press).

Miller MP, (1997). Tools for population genetic analysis (TFPGA 1.3): a windows program for the analysis of allozyme and molecular population genetic data. Computer software distributed by author.

Nei M, Fuerst PA and Chakraborty R, (1978). Subunit molecular weight and genetic variability of proteins in natural populations. Proc. Natl. Acad. Sci. USA 75: 3359-3362.

Ostlie KR, Hutchinson WD and Hellmich RL, (1997). Bt corn and European corn borer, long term success through resistance management. NCR publication 602, University of Minnesota, Saint Paul.

Pasteur N, Pasteur G, Bonhomme F, Catalan J and Britton-Davidian J, (1987). Manuel Technique de Génétique par électrophorèse des protéines. Lavoisier, Paris.

Raffa KF, (1989). Genetic engineering of trees to enhance resistance to insects: Evaluating the risks of biotype evolution and secondary pest outbreak. BioScience 39: $524-534$.

Rank NE, (1992). A hierarchical analysis of genetic differentiation in a montane leaf beetle Chrysomela aeneicollis (Coleoptera: Chrysomelidae). Evolution 46: 1097-1111.

Raymond $M$ and Rousset F, (1995). GENEPOP (version 1.2), Population genetics software for exact tests and ecumenicism. J. Hered. 86: 248-249.

Roush RT, (1998). Two-toxin strategies for management of insecticidal transgenic crops: can pyramiding succeed where pesticide mixtures have not? Phil. Trans. R. Soc. Lond. B 353: 1777-1786. 
Rowell-Rahier M and Pasteels J, (1994). A comparison between allozyme data and phenotypic distances from defensive secretion in Oreina leaf-beetles (Chrysomelinae). J. Evol. Biol. 7: 489-500.

Sanchis V, (2000). Biotechnological improvement of Bacillus thuringiensis for agricultural control of insect pests: benefits and ecological implications. In: Entomopathogenic bacteria from laboratory to field application (eds Charles et al.), Kluwer Academic Publishers, p. 441-461.

Slatkin M, (1993). Isolation by distance in equilibrium and non-equilibrium populations. Evolution 47: 264-279.

Stettler RF, Bradshaw HD, Heilman PE and Hinckley TM, (1996). Biology of Populus and its implications for management and conservation. NRC Research Press, Ottawa.

Strauss SH, Howe GT and Goldfarb B, (1991). Prospects for genetic engineering of insect resistance in forest trees. Forest Ecol. Manag. 43: 181-209.

Viard F, Brémond P, Labbo R, Justy F, Delay B and Jarne P, (1996). Microsatellites and the genetics of highly selfing populations in the freshwater snail Bulinus truncatus. Genetics 142: 1237-1247.

Weir BS and Cockerham CC, (1984). Estimating F-statistics for the analysis of population structure. Evolution 38: $1358-1370$.

APPENDIX A: Allelic frequency values for each locus (Tpi, Gpi, Hbdh, Ck, Mpi, Pgm and Pep), for the 16 sample sites $(\mathrm{N}=$ number of alleles for each locus)

Locus N Cha Dan Che Nog Ard Vil Lig For Coo Con Vat Vaa Mou Ami Bou Oig All

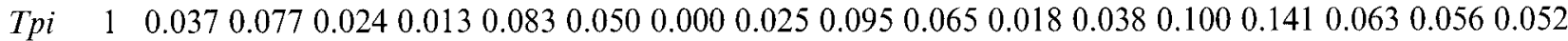

$20.000 \quad 0.0000 .0000 .0000 .0000 .0000 .0000 .0000 .0000 .0000 .0000 .0000 .0000 .0000 .0000 .0140 .001$

$\begin{array}{lllllllllllllllllll}3 & 0.000 & 0.013 & 0.000 & 0.000 & 0.000 & 0.000 & 0.000 & 0.000 & 0.000 & 0.000 & 0.018 & 0.000 & 0.000 & 0.000 & 0.000 & 0.000 & 0.002\end{array}$

$\begin{array}{llllllllllllllllllllll}4 & 0.000 & 0.000 & 0.000 & 0.000 & 0.000 & 0.000 & 0.048 & 0.025 & 0.048 & 0.043 & 0.036 & 0.013 & 0.000 & 0.000 & 0.000 & 0.000 & 0.011\end{array}$

$\begin{array}{llllllllllllllllll}5 & 0.000 & 0.000 & 0.000 & 0.000 & 0.000 & 0.013 & 0.000 & 0.000 & 0.000 & 0.000 & 0.000 & 0.000 & 0.000 & 0.000 & 0.000 & 0.000 & 0.001\end{array}$

$\begin{array}{lllllllllllllllllll}6 & 0.951 & 0.897 & 0.976 & 0.988 & 0.875 & 0.913 & 0.929 & 0.938 & 0.810 & 0.891 & 0.911 & 0.938 & 0.850 & 0.828 & 0.891 & 0.931 & 0.915\end{array}$

$\begin{array}{llllllllllllllllllllll}7 & 0.000 & 0.013 & 0.000 & 0.000 & 0.000 & 0.000 & 0.024 & 0.000 & 0.024 & 0.000 & 0.000 & 0.000 & 0.050 & 0.016 & 0.016 & 0.000 & 0.006\end{array}$

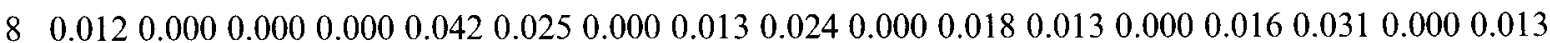

Gpi $\quad 1 \quad 0.0000 .0000 .0000 .0000 .0140 .0000 .0480 .0000 .0250 .0000 .0000 .0250 .0000 .0160 .0000 .0000 .007$

$\begin{array}{lllllllllllllllllll}2 & 0.012 & 0.000 & 0.000 & 0.000 & 0.000 & 0.000 & 0.000 & 0.000 & 0.000 & 0.000 & 0.000 & 0.000 & 0.000 & 0.000 & 0.000 & 0.000 & 0.001\end{array}$

$\begin{array}{llllllllllllllllll}3 & 0.756 & 0.900 & 0.829 & 0.838 & 0.944 & 0.825 & 0.786 & 0.900 & 0.825 & 0.932 & 0.821 & 0.825 & 0.900 & 0.891 & 0.969 & 0.819 & 0.857\end{array}$

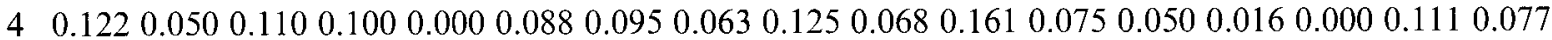

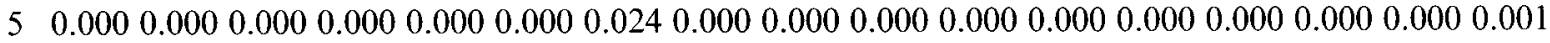

$\begin{array}{lllllllllllllllllllllllllll}6 & 0.110 & 0.050 & 0.061 & 0.063 & 0.042 & 0.088 & 0.048 & 0.038 & 0.025 & 0.000 & 0.018 & 0.075 & 0.050 & 0.078 & 0.031 & 0.069 & 0.057\end{array}$

Hbdh 10.0120 .0000 .0000 .0000 .0000 .0000 .0000 .0000 .0000 .0000 .0000 .0000 .0000 .0000 .0000 .0000 .001

$2 \quad 0.0120 .0140 .012 \quad 0.0250 .000 \quad 0.013 \quad 0.048 \quad 0.013 \quad 0.000 \quad 0.022 \quad 0.0000 .0260 .0500 .0470 .0310 .0000 .017$

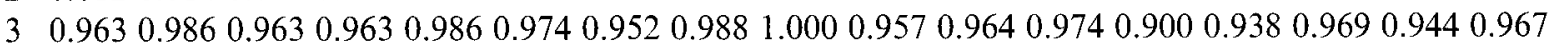

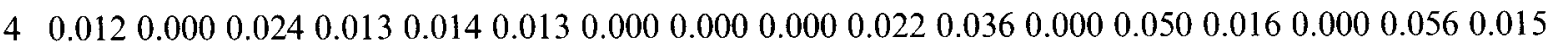

Ck $\quad 1 \quad 0.0000 .0000 .0000 .0000 .0000 .0000 .0000 .0000 .0000 .0000 .0000 .0130 .0000 .0000 .0000 .0000 .001$

$2 \quad 0.0120 .0240 .000 \quad 0.0130 .000 \quad 0.0250 .0240 .0380 .0240 .000 \quad 0.0000 .013 \quad 0.0500 .0310 .0000 .0000 .014$

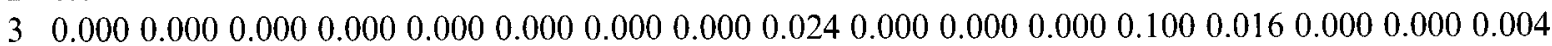

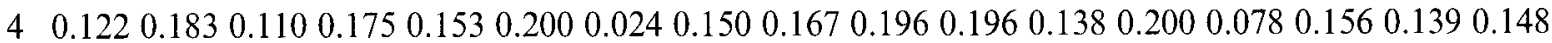

$\begin{array}{lllllllllllllllllll}5 & 0.098 & 0.122 & 0.146 & 0.163 & 0.139 & 0.150 & 0.214 & 0.125 & 0.143 & 0.109 & 0.089 & 0.150 & 0.050 & 0.141 & 0.125 & 0.167 & 0.136\end{array}$

$\begin{array}{llllllllllllllllllll}6 & 0.768 & 0.671 & 0.744 & 0.638 & 0.708 & 0.625 & 0.738 & 0.688 & 0.643 & 0.696 & 0.714 & 0.675 & 0.600 & 0.719 & 0.719 & 0.694 & 0.693\end{array}$

$\begin{array}{llllllllllllllllllllll}7 & 0.000 & 0.000 & 0.000 & 0.000 & 0.000 & 0.000 & 0.000 & 0.000 & 0.000 & 0.000 & 0.000 & 0.013 & 0.000 & 0.016 & 0.000 & 0.000 & 0.002\end{array}$

$\begin{array}{llllllllllllllllll}8 & 0.000 & 0.000 & 0.000 & 0.013 & 0.000 & 0.000 & 0.000 & 0.000 & 0.000 & 0.000 & 0.000 & 0.000 & 0.000 & 0.000 & 0.000 & 0.000 & 0.001\end{array}$

Mpi $\quad 1 \quad 0.0000 .0130 .0000 .0000 .0000 .0000 .0000 .0000 .0000 .0000 .0360 .0130 .0000 .0000 .0000 .0000 .004$

$\begin{array}{lllllllllllllllllllllll}2 & 0.088 & 0.103 & 0.122 & 0.122 & 0.069 & 0.100 & 0.143 & 0.100 & 0.024 & 0.130 & 0.071 & 0.050 & 0.100 & 0.031 & 0.078 & 0.097 & 0.089\end{array}$

$\begin{array}{llllllllllllllllllllll}3 & 0.038 & 0.051 & 0.012 & 0.014 & 0.056 & 0.000 & 0.071 & 0.075 & 0.048 & 0.065 & 0.018 & 0.013 & 0.000 & 0.078 & 0.047 & 0.0420 .039\end{array}$

$\begin{array}{lllllllllllllllllll}4 & 0.838 & 0.808 & 0.866 & 0.811 & 0.819 & 0.850 & 0.762 & 0.800 & 0.929 & 0.804 & 0.821 & 0.900 & 0.750 & 0.891 & 0.859 & 0.847 & 0.839\end{array}$

$\begin{array}{lllllllllllllllllllllll}5 & 0.038 & 0.026 & 0.000 & 0.014 & 0.028 & 0.050 & 0.024 & 0.025 & 0.000 & 0.000 & 0.054 & 0.025 & 0.050 & 0.000 & 0.000 & 0.014 & 0.021\end{array}$

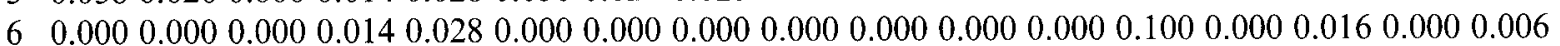

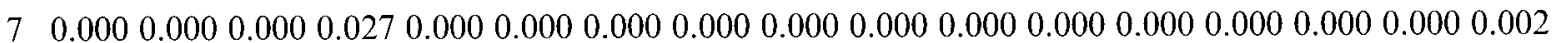


APPENDIX A (Continued)

Locus N Cha Dan Che Nog Ard Vil Lig For Coo Con Vat Vaa Mou Ami Bou Oig All

Pgm $1 \quad 0.0000 .0130 .0000 .0000 .0000 .0130 .0000 .0000 .0240 .0000 .0360 .0000 .0000 .0000 .0470 .0140 .009$

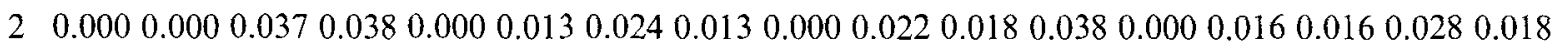

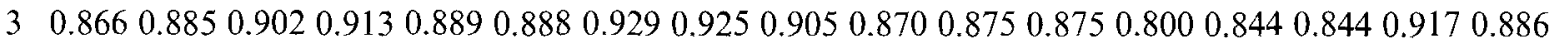

$4 \quad 0.000 \quad 0.0000 .0000 .0000 .0000 .0000 .0000 .0000 .0000 .0000 .0180 .0000 .0000 .0000 .0000 .0000 .001$

$\begin{array}{lllllllllllllllllll}5 & 0.110 & 0.103 & 0.061 & 0.038 & 0.111 & 0.088 & 0.048 & 0.063 & 0.071 & 0.109 & 0.054 & 0.088 & 0.150 & 0.125 & 0.078 & 0.042 & 0.080\end{array}$

$\begin{array}{llllllllllllllllll}6 & 0.012 & 0.000 & 0.000 & 0.000 & 0.000 & 0.000 & 0.000 & 0.000 & 0.000 & 0.000 & 0.000 & 0.000 & 0.000 & 0.000 & 0.000 & 0.000 & 0.001\end{array}$

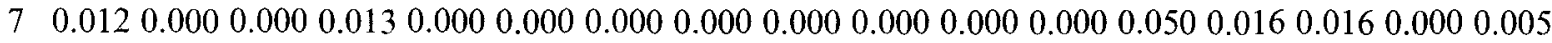

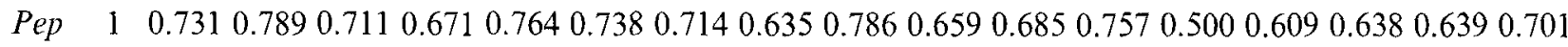

20.0000 .0000 .0000 .0000 .0000 .0000 .0000 .0140 .0000 .0230 .0000 .0000 .0000 .0000 .0000 .0000 .002

$\begin{array}{llllllllllllllllllllll}3 & 0.269 & 0.211 & 0.289 & 0.329 & 0.236 & 0.263 & 0.286 & 0.351 & 0.214 & 0.318 & 0.315 & 0.243 & 0.500 & 0.391 & 0.345 & 0.361 & 0.295\end{array}$

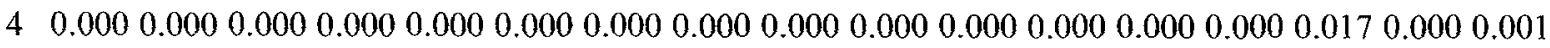

